\title{
EVALUATION OF THE RELIABILITY OF BUILDING STRUCTURES IN SIMULIA ABAQUS: MODELING OF STOCHASTIC MATERIAL PROPERTIES
}

\author{
Alexander I. Khvostov ${ }^{1}$, Sergei I. Zhukov' ${ }^{2}$ Sergey N. Tropkin ${ }^{3}$, \\ Andrey Y. Chauskin ${ }^{4}$ \\ ${ }^{1}$ LLC Auriga, Moscow, RUSSIA \\ ${ }^{2}$ Research Computing Center of Moscow State University, Moscow, RUSSIA \\ ${ }^{3}$ LLC "TESIS", Moscow, RUSSIA \\ ${ }^{4}$ REM Systems LLC, Moscow, RUSSIA
}

\begin{abstract}
This article describes a software module component integrated with the SIMULIA Abaqus engineering analysis software package and designed to simulate random values of material parameters in a finite element model based on specified statistical characteristics, with the possibility of taking into account the physical nonlinearity of material behavior under various combinations of loads and influences. The target group of materials under study is materials of load-bearing elements of building structures, such as concrete, stone, steel. This software module can be recommended for use by specialists, engineers and scientists engaged in probabilistic analysis of the reliability of structures of buildings and structures, apparatus, machines, devices, with the combined use of complexes of computer modeling and engineering analysis. Has a certificate of state registration of the computer program "AS for modeling stochastic properties of materials" No. 2019667439 dated 12.24.2019.
\end{abstract}

Keywords: Finite element method, theory of reliability, random numbers, computer modeling, programming

\section{ОЦЕНКА НАДЁЖНОСТИ СТРОИТЕЛЬНЫХ КОНСТРУКЦИЙ В SIMULIA ABAQUS: МОДЕЛИРОВАНИЕ СТОХАСТИЧЕСКИХ СВОЙСТВ МАТЕРИАЛА}

\author{
А.И. Хвостов ${ }^{1}$, С.И. Жуков ${ }^{2}$, С.Н. Тропкин ${ }^{3}$, А.Ю. Чаускин ${ }^{4}$ \\ ${ }^{1}$ ООО «Аурига», Москва, РОССИЯ \\ ${ }^{2}$ НИВЦ МГУ, Москва, РОССИЯ \\ ${ }^{3}$ ООО «ТЕСИС», Москва, РОССИЯ \\ ${ }^{4}$ ООО «РЕМ Системс», Москва, РОССИЯ
}

\begin{abstract}
Аннотация. В данной статье описывается компонент программного модуля интегрированный с программным комплексом инженерного анализа SIMULIA Abaqus и предназначенный для моделирования случайных значений параметров материала в конечно-элементной модели на основе заданных статистических характеристик, с возможностью учёта физической нелинейности поведения материала при различных сочетаниях нагрузок и воздействиях. Целевая группа исследуемых материалов - материалы несущих элементов строительных конструкций, такие как бетон, камень, сталь. Данный программный модуль может быть рекомендован для применения специалистами, инженерами и учёными, занимающимися вероятностным анализом надёжности конструкций зданий и сооружений, аппаратов, машин, приборов, при совместном использовании комплексов компьютерного моделирования и инженерного анализа. Имеет свидетельство государственной регистрации программы для ЭВМ «АС моделирования стохастических свойств материалов» №2019667439 от 24.12.2019.
\end{abstract}

Ключевые слова: Метод конечных элементов, теория надёжности, случайные числа, компьютерное моделирование, программирование 


\section{INTRODUCTION}

Currently, ensuring the mechanical safety of buildings, structures and their structures is regulated by regulatory legal acts based on the semi-probabilistic method of limit states using reliability coefficients. The calculation methods laid down in the standards do not allow the designer to obtain quantitative indicators of the reliability of the facility being developed. The available qualitative characteristic of reliability is subjective, depends significantly on the qualifications of experts and often leads to inexpedient economic decisions, including those based on personal reinsurance of a specialist in the design process. On the other hand, there are cases when the reliability of objects of increased responsibility is lower than objects of the normal and reduced levels. It should also be noted that at present, damage and defects in structures are often the result of design errors. One of the significant "modern" factors affecting the probability of error is the lack of time - the generally accepted principles of finding optimal solutions based on iterative design and experimental verification are now becoming less and less relevant.

One of the effective solutions to this problem is the use of universal software systems for numerical modeling, which have flexible customization options: development of new types of material, finite elements, solver customization, and much more.

\section{USING THE USER SUBROUTINE UMAT}

The finite element method initially developed as a generalization and systematization of methods for solving problems in structural mechanics. Later it found wide application in other fields of science and technology [6]. It is rather difficult to create a universal graphical interface that would satisfy the highly specific requirements of an evergrowing number of extremely diverse problems solved using the finite element method. There are user subroutines for additional customization of the SIMULIA Abaqus software package. The principle of working with them is that the core of the software complex calls during the calculation a set of user-written subroutines that overload the corresponding functionality in Abaqus.

User subroutines are an extremely powerful tool that allows you to extend some of the functionality of the software package for which the usual interface for inputting initial data imposes too strict restrictions. Custom subroutines provide the ability to flexibly define material properties and behavior, initial and boundary conditions, and even directly calculate local stiffness matrices for custom finite element types.

User-defined routines are usually written in FORTRAN. Subroutines cannot call each other, but a number of utilities can be called from the Abaqus programming interface.

In Abaqus, the user can create his own type of material. A custom UMAT subroutine is used to set its behavior.

The UMAT subroutine is designed to simulate the nonlinear behavior of materials. In this article, we restrict ourselves to generating a model with random, locally given initial elastic properties. UMAT is called at each Gaussian integration point of the finite element when constructing its local stiffness matrix at each loading step. From the data passed by the Abaqus kernel to the UMAT subroutine, we need the stress tensor $\sigma=$ STRESS (NTENS) and the strain tensor increment $\Delta \varepsilon=D S T R A N$ (NTENS). We must obtain the Jacobi matrix:

$$
J=D D S D D E(i, j)=\frac{\Delta \sigma}{\Delta \varepsilon}=E(i, j)=E_{i j}
$$

which in our case is equal to the tensor of the elastic constants of the material and stress at the next loading step

$$
\sigma_{k+1}=\sigma_{k}+E \Delta \varepsilon_{k} ;
$$

A detailed description and a complete list of arguments for the UMAT subroutine can be found in the documentation for the SIMULIA Abaqus software package. 


\section{BOX-MULLER TRANSFORM}

Typically, algorithms for (pseudo) random number generators on personal computers generate a sequence of numbers that obeys a uniform distribution. However, many physical quantities have a distribution close to normal (and tending to it, according to the Lyapunov theorem), which is implemented by various kinds of special sensors used in cryptography. The question of converting a uniform distribution into a normal distribution has been studied in detail for a long time, and the method of polar coordinates proposed by George Box, Mervyn Mueller and George Marsaglia in 1958 has become the most widespread [9]. In this work, we used the following version of the BoxMuller transformation.

Let and be independent random variables uniformly distributed on the interval $[-1 ; 1]$. We calculated $s=x^{2}+y^{2}$. If $s>1$ or $\mathrm{S}=0$, then the values $x$ and $y$ should be regenerated again. If the condition $0<\mathrm{S} \leq 1$ is satisfied, then further by the formulas it is necessary to calculate:

$$
\begin{aligned}
& z_{0}=x \sqrt{\frac{-2 \ln s}{s}}, \\
& z_{1}=y \sqrt{\frac{-2 \ln s}{s}} ;
\end{aligned}
$$

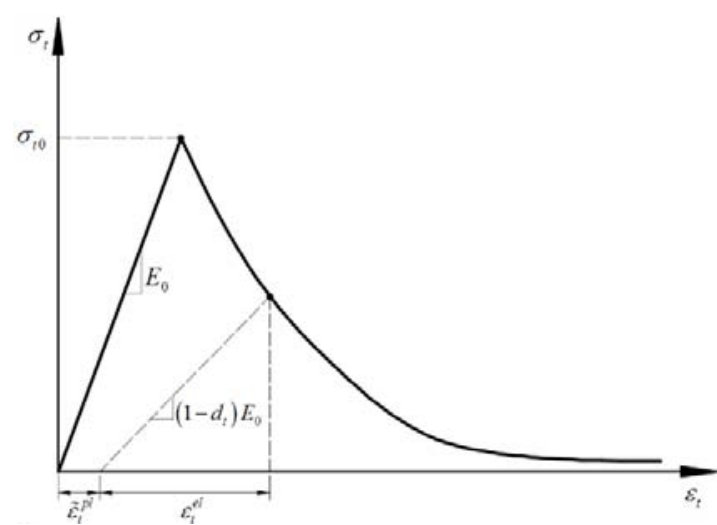

a)
Here $z_{0}$ and $z_{1}$ are independent quantities that satisfy the standard normal distribution.

The method considered above allows one to obtain a pair of independent normally distributed random variables with mathematical expectation 0 and variance 1 . In order to obtain a distribution with other characteristics, it is sufficient to multiply the result of the function by the standard deviation and add the mathematical expectation.

Young's modulus for an isotropic material with normally distributed properties is calculated by the formula:

$$
E=M[E]+\sigma[E] \cdot z
$$

where $M[E]$ is expected value and $\sigma[E]$ is standard deviation of the Young's modulus of the material.

\section{MODELING MATERIAL WITH ACCUMULATED DAMAGE}

As an example, the first approximation of modeling reinforced concrete structures with variable values of the modulus of elasticity of concrete is considered. The value of the modulus of elasticity in building structures is an important indicator both in determining the strength and deformation characteristics of load-bearing

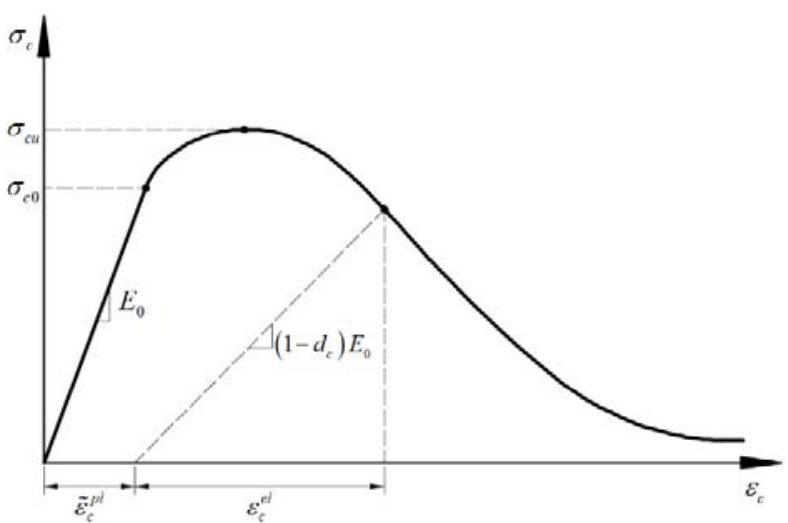

b)

Figure 1. Diagrams of concrete deformation described by the CDP model: a) in tension; b) in compression 
structures, and is directly related to meeting the requirements for the first and second groups of limiting states. For example, Abaqus implements a model of fracture of brittle materials CDP [3, 4] (Concrete Damage Plasticity), in which the decrease in the elastic modulus is expressed through the scalar value of material damage $d$ and the initial Young's modulus $E_{0}$ :

$$
E=(1-d) E_{0}
$$

A formulation close to this implementation is also regulated by the Chinese standards GB 50010-2010 (applicable for concretes of the C20-C80 class with a density of $2200-2400 \mathrm{~kg}$ $/ \mathrm{m}^{3}$ ), for example, when determining tensile stresses:

$$
\sigma=\left(1-d_{t}\right) E_{c} \varepsilon
$$

Integrally, Young's modulus is also related to the dynamic characteristics of the object, which allows, on the basis of a comparison of the experimentally obtained natural frequencies of the structure and those obtained in the process of virtual tests, to speak about their residual resource after a long time of operation or after a seismic effect of high intensity, where there are residual damage to structures [10].

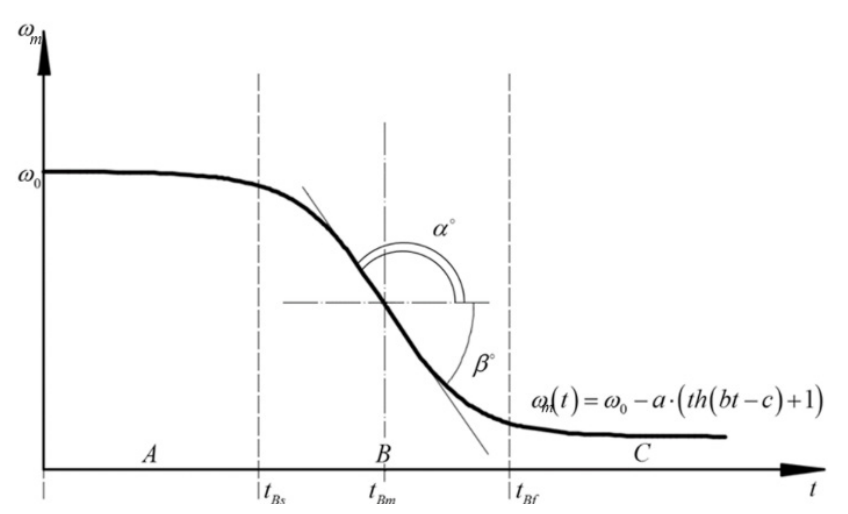

\section{MODELING OF REINFORCED CONCRETE STRUCTURES WITH A RANDOM DISTRIBUTION OF YOUNG'S MODULUS OF HEAVY CONCRETE IN VOLUME}

Based on the current regulatory legal acts, in particular GOST 28570-2019 for testing concrete samples taken from structures, the values of concrete compressive strength tend to the normal distribution law and are described by such indicators as standard deviation, coefficient of variation and mathematical expectation. It should be noted that for concretes with low strength indices, the application of the normal distribution law may be incorrect (for example, for aerated concrete, where there may be negative strength in a significant distribution range, which contradicts physical principles). The example presented below is a demonstrator of the previously described methods and is a prerequisite for the development of practical, verified methods for modeling such a class of problems.

Below is the procedure for user actions when using stochastic values of material parameters by the example of modeling an elementary structure - a pylon or a section of a wall. Omitting the classic, basic stages of developing a finite element model, the user specifies the required values in the parameters of the custom material, as well as the path to the
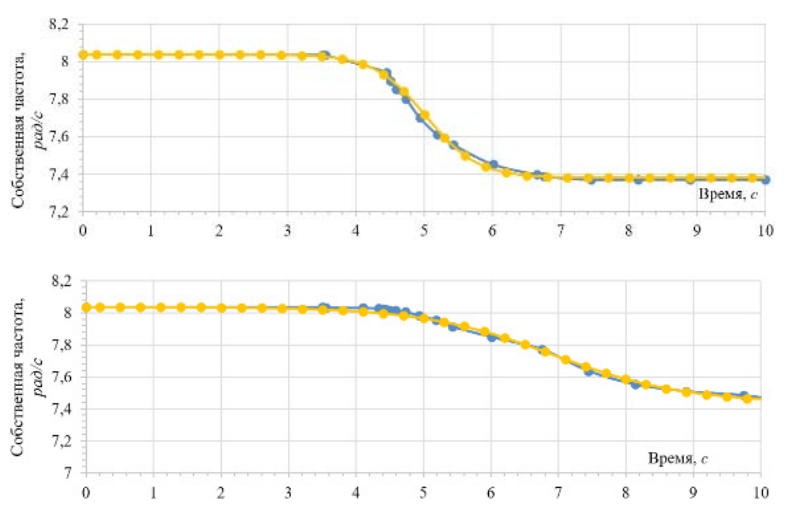

Figure 2. Derived function described in [10] and graphs of changes in the values of natural vibration frequency depending on Young's modulus for a reinforced concrete monolithic frame obtained in the process of virtual tests and calculated analytically without them 


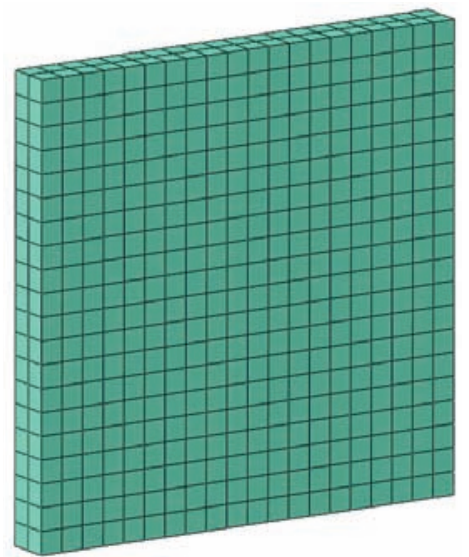

a)

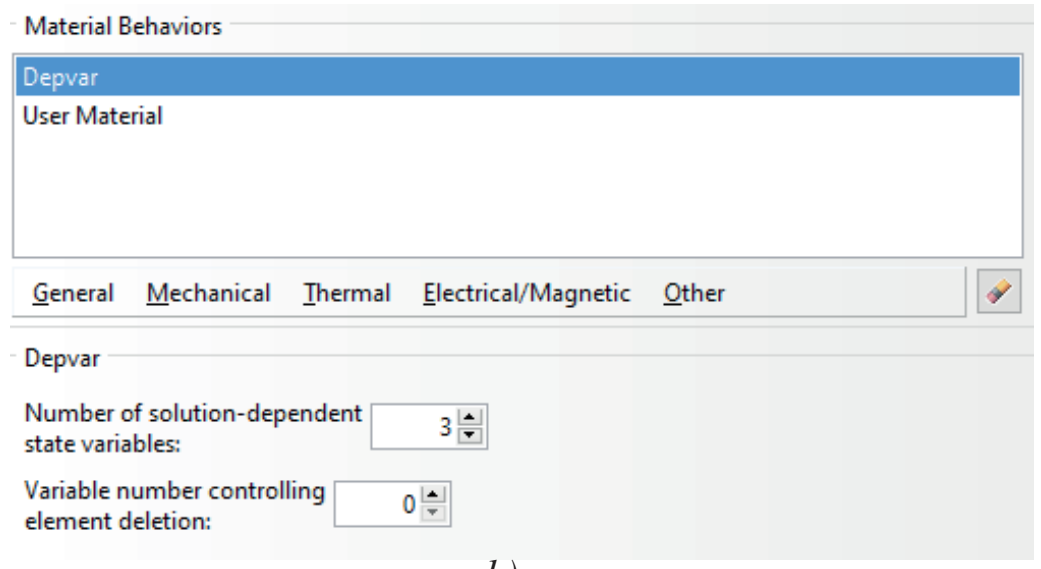

b)

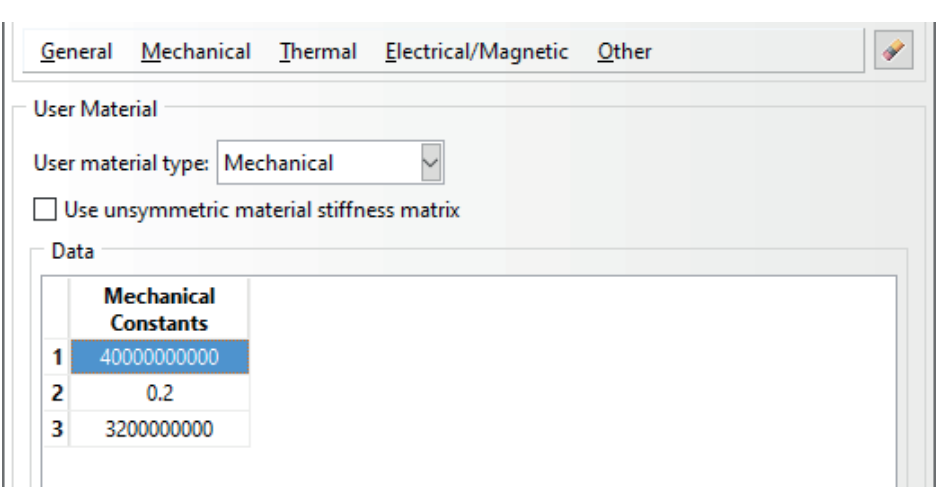

c)

\begin{tabular}{|l|}
\hline Preprocessor Printout \\
$\square$ Print an echo of the input data \\
$\square$ Print contact constraint data \\
$\square$ Print model definition data \\
$\square$ Print history data \\
Scratch directory: \\
\hline \\
\hline User subroutine file: \\
\hline D: lumat-st.for \\
\hline Results Format \\
\hline ODB O SIM $\bigcirc$ Both \\
\hline
\end{tabular}

d)

Figure 3. a) Finite element mesh of the test model, elements C3D8-8-node hexagonal FE of a continuous medium with a linear shape function; b) Setting the number of variables in the graphical interface; c) Description of variable values; d) Description of the path to the subroutine

custom subroutine in the menu for starting the calculation task in Abaqus. The mathematical expectation and standard deviation of Young's modulus are taken as variables $M[E]$ and $\sigma[E]$, as well as Poisson's ratio $\mu$.
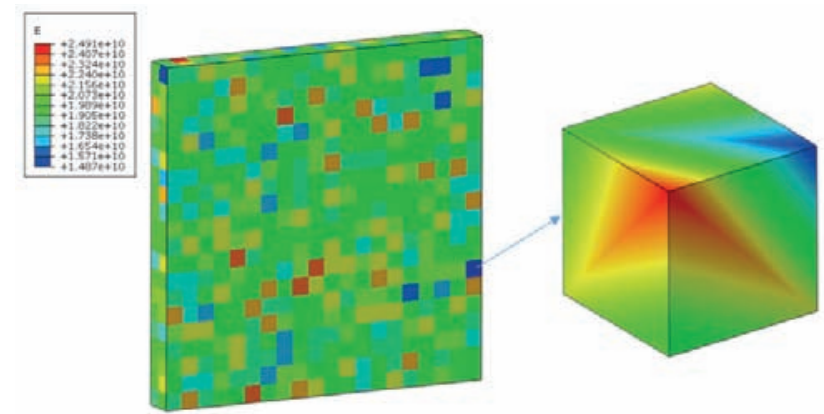

Figure 4. Mosaic of Young's modulus distribution for the test model, $\mathrm{Pa}$
Based on the verification tests performed, the values of Young's modulus for the FE model were obtained, without taking into account the correlation of values in space, which in reality may be a random spread of poor quality of the material obtained during the production of work. Further, virtual tests were performed for two cases: 1. For the above-described elementary structure of a type of wall or pylon section, with the calculation of the calculated values of vertical stresses for concrete of class B40;

2. For a reinforced column (concrete class B25, steel A400), with a random value obtained for the entire volume of Young's modulus and subsequent analytical analysis of reliability over the entire height. 

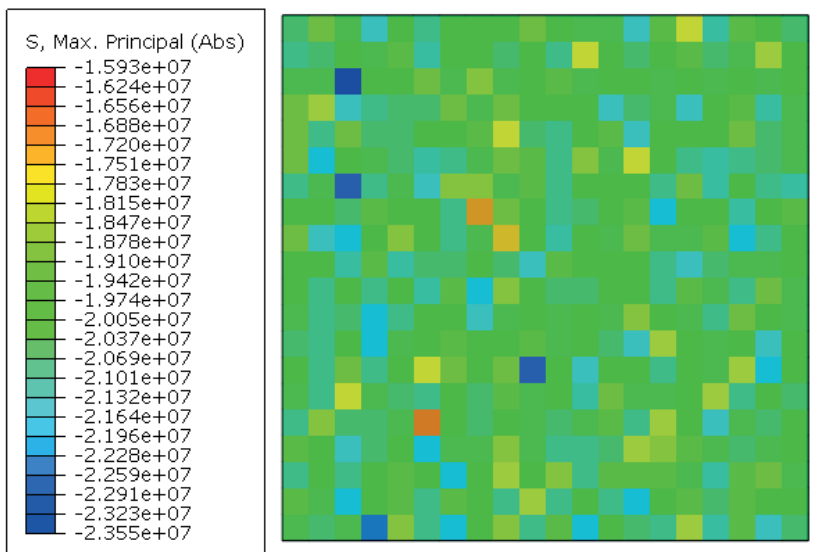

a)

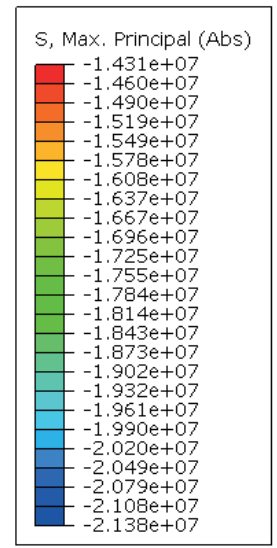

$-1.138 \mathrm{e}+07$

Figure 5. Random design realizations of the mosaic of the distribution of the main stresses in concrete of class B40 of the wall model: a) Failure case (maximum compressive stress $23.55 \mathrm{MPa}$ ); b) Case to failure (maximum compressive stresses $21.38 \mathrm{MPa}$ ). Total failures for 500 virtual tests 2. Reliability value $99.96 \%(\beta \approx 3,35)$.
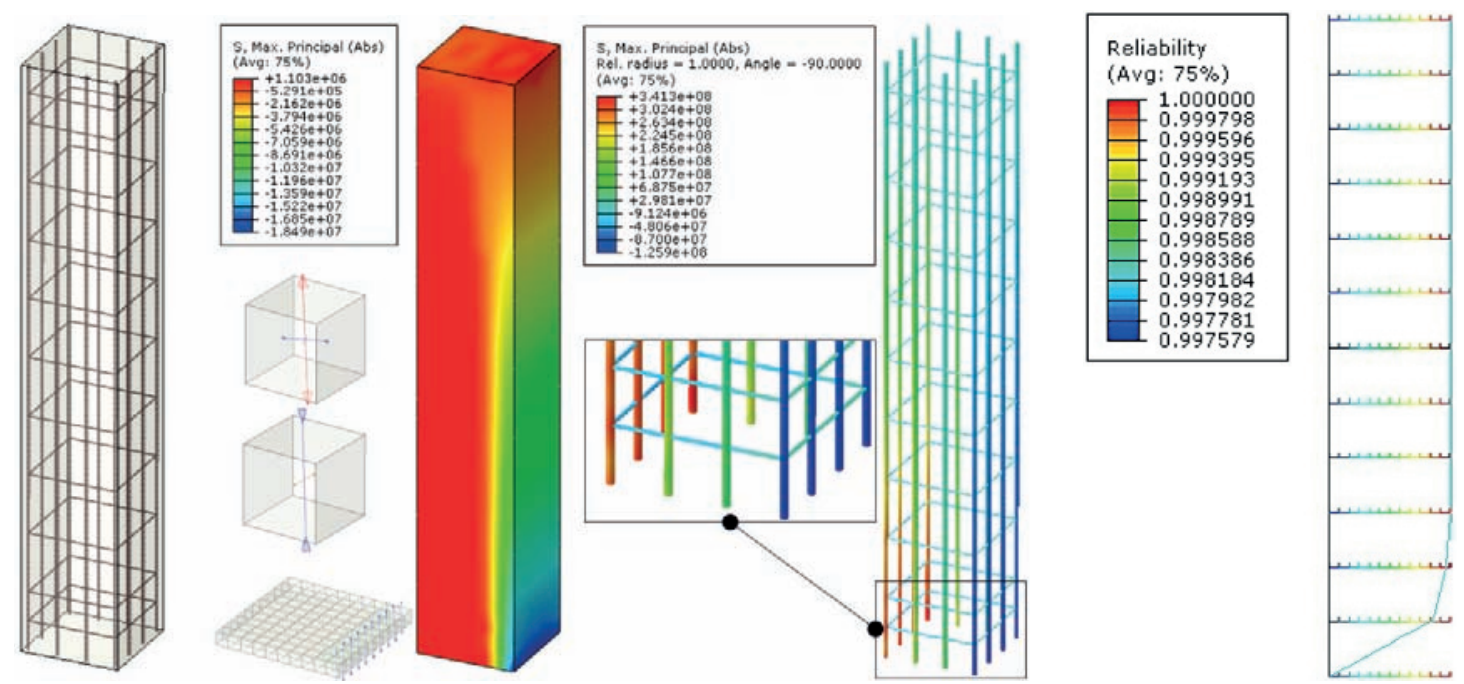

Figure 6. Control solution based on parametric optimization in a nonlinear formulation using volumetric finite elements (elements of the C3D8R and B31R types) (maximum stress in reinforcement $341 \mathrm{MPa}$, compressive stresses in concrete $18.5 \mathrm{MPa}$ ). Reliability diagram along the column height calculated for a bar analogue.

In the first case, after 500 virtual tests, local vertical internal stresses in concrete in 498 cases did not exceed the permissible design values. In 2 cases, these stresses were exceeded and can be identified as a local failure (but not a failure of the structure as a whole). At the same time, the reliability index $\beta=3.35$, which is a relatively high indicator of reliability for load-bearing structures, based, for example, on the recommendation data of EN 1990: $2002+$ A1. Eurocode - Basis of structural design (for objects of normal level of responsibility with an estimated service life of 50 years is 3.8).

In the second case, for one test, the distribution of the reliability value along the column height was obtained, taking into account the arising internal forces. For this example, using custom output data, for a bar analogue, a reliability diagram was 
obtained for the entire structural element, which is a convenient integral indicator for assessing mechanical safety.

\section{CONCLUSIONS}

1. Based on the performed analytical and numerical studies, using the software module for generating random values of material parameters for numerical finite element models, the following conclusions can be drawn:

2. 1. A software module for generating random values of material parameters has been developed and verified, which allows for numerical analysis in a stochastic formulation both for the construction industry and for other technical areas, which is also important in the development of new products using modern materials that require study and appropriate certification;

3.2. The practical application of the method in the universal complex of computer modeling Abaqus is shown: a series of virtual tests was performed with the calculation of the reliability value and the reliability index, a numerical-analytical method for constructing a reliability diagram was applied, which allows to evaluate sections of structures that do not meet the requirements of strength, stability and rigidity in an integrated manner in a convenient form.

\section{REFERENCES}

1. GB 50010-2010. Code for design of concrete structures. National standard of People's Republic of China. China architecture \& building press - China - 2010. - $441 \mathrm{p}$.

2. ISO 2394:2015. General principles on reliability for structures [Text] - Switzerland, 2015. - $111 \mathrm{p}$.

3. Lee J, Fenves GL. Plastic-Damage Model for Cyclic Loading of Concrete Structures. J. Engng. Mech, - 1998. - Vol. 124 (8). - pp. 892-900.

4. Lubliner J., Oliver J., Oller S., Onate E. A Plastic-Damage Model for Concrete // Int.
J. Solids Struct. - 1989. - Vol. 25 (3). - pp. 229-326.

5. Shen S. Stochastic material characterization of heterogeneous media with randomly distributed material properties. Doctor of Philosophy [Dissertation], 12.2012. - The Graduate Faculty of The University of Akron, USA, 2012. -212 p.

6. Zienkiewicz, O.C. The Finite Element Method: vol.1 The Basis. [Text] / O.C. Zienkiewicz, R.L. Taylor // ButterworthHeinemann, 2000. - 348 p.

7. Verifikatsionnyy otchot po PK Abaqus. Svidetel'stvo RAASN o verifikatsii PS № 05/ SIMULIA Abaqus/2014 ot 20.03.2014 goda.: v 4 t. [Verification report on PC Abaqus. RAASN certificate of verification of PS No. 05 / SIMULIA Abaqus / 2014 dated 03/20/2014: in 4 volumes] / FGBOU VPO «MGSU», LLC «TESIS». - Moscow, 2014

8. Standard of RF GOST 27751-2014. Nadezhnost' stroitel'nykh konstruktsiy. Osnovnyye polozheniya [Reliability for constructions and foundations. General principles]. Moscow : Standartinform, 2015 - 16 p.

9. Knut D.E. Iskusstvo programmirovaniya. Tom 2. Poluchislennyye algoritmy (3-ye izdaniye, ispravlennoye $\mathrm{i}$ dopolnennoye) [The art of programming. Volume 2. Obtained algorithms (3rd edition, revised and enlarged)], Moscow: Dialektika, 2019.

10. Chauskin A. YU. Assessment of the reliability of a monolithic reinforced concrete building under the influence of a maximum flow rate earthquake [Tekst]. Candidate of Techn. Science: 05.23.17. Moscow, $2017-157$ p.

\section{СПИСОК ЛИТЕРАТУРЫ}

1. GB 50010-2010. Code for design of concrete structures. National standard of People's Republic of China. China architecture \& building press - China - 2010. - $441 \mathrm{p}$.

2. ISO 2394:2015. General principles on reliability for structures [Text] - Switzerland, 2015. - $111 \mathrm{p}$. 
3. Lee J, Fenves GL. Plastic-Damage Model for Cyclic Loading of Concrete Structures. J. Engng. Mech, - 1998. - Vol. 124 (8). - pp. 892-900.

4. Lubliner J., Oliver J., Oller S., Onate E. A Plastic-Damage Model for Concrete // Int. J. Solids Struct. - 1989. - Vol. 25 (3). - pp. 229-326.

5. Shen S. Stochastic material characterization of heterogeneous media with randomly distributed material properties. Doctor of Philosophy [Dissertation], 12.2012. - The Graduate Faculty of The University of Akron, USA, 2012. - $212 \mathrm{p}$.

6. Zienkiewicz, O.C. The Finite Element Method: vol.1 The Basis. [Text] / O.C. Zienkiewicz, R.L. Taylor // ButterworthHeinemann, 2000. - 348 p.
7. Верификационный отчёт по ПК Abaqus. Свидетельство РААСН о верификации ПС № 05/SIMULIA Abaqus/2014 от 20.03.2014 года.: в 4 т. [Текст] / ФГБОУ ВПО «МГСУ», ООО «ТЕСИС». - Москва, 2014

8. ГОСТ 27751-2014. Надежность строительных конструкций. Основные положения [Текст]. - Москва : Стандартинформ, 2015 - 16 с.

9. Кнут Д.Э. Искусство программирования. Том 2. Получисленные алгоритмы (3-е издание, исправленное и дополненное), Диалектика, 2019 г.

10. Чаускин А. Ю. Оценка надёжности монолитного железобетонного здания при воздействии максимального расчётного землетрясения [Текст]. Канд. техн. наук: 05.23.17: защищена 21.06.17: утв. 12.10.18-Москва, 2017-157 с.
Alexander I. Khvostov, Lead Programmer, LLC Auriga, 117587 Moscow, Varshavskoe shosse, 125, building 16A; phone +7 (903) 685-79-91; E-mail: alexander.khvostov@ auriga.com

Sergei I. Zhukov, PhD in Physics and Mathematics, Lead Programmer, Research Computing Center, Moscow State University, 119991 Moscow, Leninskie Gory, Building 1, Building 4; phone +7 (977) 333-56-07; E-mail: serge. zhukov@auriga.com

Sergey N. Tropkin, candidate of technical sciences, leading engineer of TESIS LLC; 127083 Moscow, st. Yunnatov, 18; phone: +7 (495) 612-44-22; E-mail: st@ tesis.com.ru

Andrey Y. Chauskin, Candidate of Technical Sciences, General Director of REM Systems LLC; chief expert of OOO DPI Vostokproektverf; 121205 Russia, Moscow, Skolkovo Innovation Center; phone: +7 (977) 972-33-84; E-mail: a.chauskin@remsystems.ru
Александр Игоревич Хвостов, ведущий программист ООО «Аурига», 117587 Москва, Варшавское шоссе, д. 125, стр. 16А; телефон +7(903)685-79-91; E-mail: alexander.khvostov@auriga.com

Сергей Иванович Жуков, кандидат физико-математических наук, ведущий программист НИВЦ МГУ, 119991 Москва, Ленинские горы, дом 1, стр. 4; телефон +7(977)333-56-07; E-mail: serge.zhukov@auriga.com

Сергей Николаевич Тропкин, кандидат технических наук, ведущий инженер ООО «ТЕСИС»; 127083 Москва, ул. Юннатов, д. 18; телефон: +7(495)612-44-22; E-mail: st@ tesis.com.ru

Андрей Юрьевич Чаускин, кандидат технических наук, генеральный директор ООО «РЕМ Системс»; главный эксперт ООО ДПИ «Востокпроектверфь»; 121205 Россия, г. Москва, Инновационный центр «Сколково»; телефон: +7(977)972-33-84; E-mail: a.chauskin@ remsystems.ru 